\title{
Prevalence of Gastrointestinal Helminth Parasites in Gallus gallus domesticus in Lucknow, U. P, India
}

\author{
Kamal Jaiswal, Suman Mishra, Anjum Bee* \\ Department of Zoology, Babasaheb Bhimrao Ambedkar University Lucknow, India
}

Received April 9, 2020; Revised June 16, 2020; Accepted July 1, 2020

\begin{abstract}
Cite This Paper in the following Citation Styles
(a): [1] Kamal Jaiswal, Suman Mishra, Anjum Bee, "Prevalence of Gastrointestinal Helminth Parasites in Gallus gallus domesticus in Lucknow, U. P, India," Advances in Zoology and Botany, Vol. 8, No. 5, pp. 422 - 430, 2020. DOI: 10.13189/azb.2020.080506.
\end{abstract}

(b): Kamal Jaiswal, Suman Mishra, Anjum Bee (2020). Prevalence of Gastrointestinal Helminth Parasites in Gallus gallus domesticus in Lucknow, U. P, India. Advances in Zoology and Botany, 8(5), 422 - 430. DOI: 10.13189/azb.2020.080506.

Copyright $\odot 2020$ by authors, all rights reserved. Authors agree that this article remains permanently open access under the terms of the Creative Commons Attribution License 4.0 International License

\begin{abstract}
Poultry industry occupies an important position in the provision of animal protein and plays a vital role in the national economy. Helminthiasis caused by helminth parasites is one of the most common infections affecting health of poultry and indirectly leading to great economic loss among small livestock holders. The prevalence of gastrointestinal helminth parasites in Gallus gallus domesticus was studied from January 2017 to December 2019 in the parasitology laboratory of Zoology Department, Babasaheb Bhimrao Ambedkar University, Lucknow, India. In this study, a total of 557 domestic fowls were examined to identify the different types of gastrointestinal helminth infections. During regular examination of helminth parasites, the highest prevalence was observed for Ascaridia galli (41.7\%), followed by Cotugnia diagnopora (17.6\%), Raillietina tetragona (11\%), Heterakis gallinarum (7.4\%) and Raillietina cesticillus (6.64\%). In the monsoon season, prevalence was found to be higher than the summer and winter. Females were found to be more infected than the males. There was no trematode infection detected during the study period. The gross pathological lesions were observed in case of Heterakis gallinarum infection. The results of this study suggest that both nematodes and cestodes are prevalent in domestic fowls in the studied area.
\end{abstract}

Keywords Helminths, Gastrointestinal, Domestic Fowl, Monsoon, Gross Pathology, Prevalence

\section{Introduction}

The chicken Gallus gallus domesticus is believed to have descended from the wild Indian and South East Asian red jungle fowl [1]. Birds are an important part of the ecosystem as they play vital role in ecological, medicinal, nutritional and economical point of view. Poultry farming is the process of raising domesticated birds such as chickens and ducks for the purpose of producing meat or egg for food. India has 498 million poultry population with an average growth rate of $8-10 \%$ per annum. India ranks third in egg production and sixth in broiler meat production [2].

Poultry farming developed enormously in recent years and has become one of the most demanding forms of animal husbandry activities. Though the impact of parasitic diseases in farm birds, reared on cage systems have diminished due to modernization in poultry farming and bio security measures, farm birds maintained on deep litter system and backyard free ranging birds still remain susceptible to parasitic infection via litter droppings and scavenging habits. The domestic chicken feeds on a wide range of food substances. This range from grains, fruits to insects which may harbour infective stages of parasites thereby predisposing them to parasites particularly gastro-intestinal parasites $[3,4]$. These parasitic infections may cause considerable damage and great economic loss to the poultry industry due to malnutrition, decreased feed conversion ratio, weight loss, lowered egg production and death in young birds. Improved poultry management practices are responsible for the reduction in incidence of 
parasitic infections.

Helminths constitute the most important group of gastrointestinal parasites of fowl both in a number of species and extent of damage they cause; the main genera of nematode responsible for infection in fowl include Capillaria, Heterakis, and Ascaridia [5] additionally, cestodes of significant importance are of the two genera Railletina and Hymenolepis. The trematodes infection is not very common in domestic fowl. In villages free range management system is used to raise domestic fowl with little or no supplementary feeding and without any veterinary care thereby exposing them to parasitic infection [6]. Parasitism ranks high among factors that serve as a threat to chickens, the presence of a few parasites does not usually cause a problem; however, a large number can have a devastating effect on growth, egg production, and overall health. The Helminths are the most important group of parasites that affect the chickens both in terms of number and extent of damage caused to the gastrointestinal tract in the chickens.

So, keeping in view the importance of these parasites in chickens, this study undertaken to find out the prevalence of gastrointestinal helminth parasites of the chickens (Gallus gallus domesticus) especially in the Lucknow,
Uttar Pradesh, India, so that treatment strategy can be made accordingly and to provide guidelines in adopting the preventive measures to control the parasitic infection.

\section{Materials and Methods}

\subsection{Study Area}

The study was conducted in and around Lucknow, stands at an elevation of approximately 123 meters $(404 \mathrm{ft})$ above sea level. Lucknow district covers an area of 2,528 square kilometres (976 sq mi) $[7,8]$. Bounded on the east by Barabanki, on the west by Unnao, on the south by Raebareli and in the north by Sitapur, Lucknow sits on the northwestern shore of the Gomti River. This city has a humid subtropical climate with cool, dry winters from mid-November to February and dry, hot summers with thunderstorms from late March to June. The rainy season is from July to September when the city gets an average rainfall of 896.2 millimetres (35.28 inches) from the south-west monsoon winds, and occasionally frontal rainfall will occur in January. In winter the maximum temperature is around $25^{\circ} \mathrm{C}\left(77^{\circ} \mathrm{F}\right)$ and the minimum is in the range of $3{ }^{\circ} \mathrm{C}\left(37^{\circ} \mathrm{F}\right)$ to $7{ }^{\circ} \mathrm{C}\left(45^{\circ} \mathrm{F}\right)[9]$.

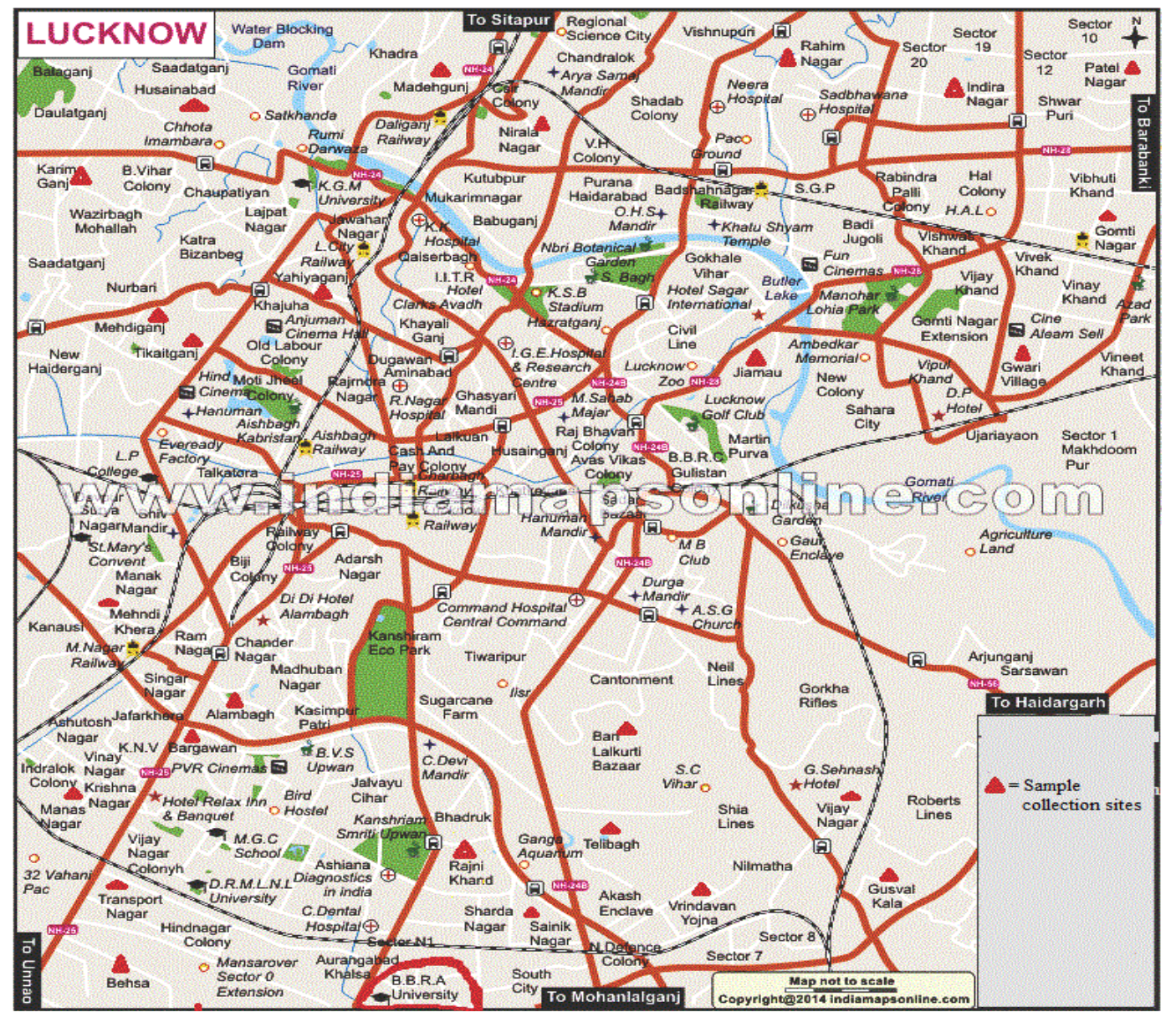

Figure 1. Map of study area showing different sample collection sites [10] 


\subsection{Study Population}

Study population includes 557 domestic chickens managed under unorganized backyard systems. The age of the studied birds was determined through information collected from owners. Growers were 12-24 weeks old and adult aged 32 weeks were collected during study period. Chickens that were old enough to fend for themselves called as growers but had not started reproducing, while adult included cocks that were mating and hens that had at least one clutch of chicks.

\subsection{Study Period}

Study was conducted during January 2017 to December 2019 in and around the Lucknow to determine the prevalence of gastrointestinal helminth parasites of domestic chicken.

\subsection{Parasitological Examination}

During the present study, the domestic fowls were collected from January 2017 to December 2019 from different regions of study sites. The hosts were then brought to the parasitology laboratory of Department of Zoology, Babasaheb Bhimrao Ambedkar University Lucknow for the parasitic examination. For the collection of endoparasites the gastro intestinal tracts of Gallus gallus domesticus were dissected thoroughly to investigate the presence of parasites, according to the procedure as described by Fowler [11].

\subsection{Preservation}

Nematodes were collected from the gastrointestinal tract of host with the help of forceps, washed in saline water and killed in hot $70 \%$ alcohol, and stored in the glycerine alcohol solution and thick parasites kept in lectophenol. Cestodes were also collected from the same host and preserved in Carnoy's fluid for the identification. Morphology of cestodes was studied by preparing a permanent slide according to the methods as described by Cable [12]. Parasites were observed under light bright field microscope (10X, 40X, 100X), and photographs were taken by Evos XL imaging microscope. Parasites were identified according to the keys and description given by Soulsby [13]. The prevalence of Helminthiasis was recorded as per formulae described by Margolis et al. [14].

\subsection{Definitions}

The ecological terms used in this study are-

Prevalence $=\frac{\text { Total number of hosts infected }}{\text { Total number of hosts examined }} \times 100$
Mean Intensity $=\frac{\text { Total number of Parasites }}{\text { Total number of host infection }}$
Relative Density or Abundance $=\frac{\text { Total number of Parasites }}{\text { Total number of hosts examined }}$

\subsection{Data Analysis}

The most common measurements of parasite population levels in hosts are prevalence, mean intensity and mean abundance [15]. Prevalence refers to the percentage of organisms infected by a particular species of parasite. Mean intensity is the number of parasites of a given species per infected host. Mean abundance refers to the number of parasites of a given species per host examined, infected and uninfected. The nomenclature used to define ecological parameters is in consistency with that of Margolis et al. [14]. The information obtained from laboratory test and observation was entered on the IBM SPSS version 20. Chi-square $(\chi 2)$ test was used to analyse the sample data. Chi-square test was used to assess whether there is a statistically significant difference in gastrointestinal parasitic infection between season, gender and age. A statistically significant association between variables was considered to exist if the calculated $\mathrm{p}$-value is less than 0.05 with $95 \%$ confidence level.

\section{Results}

\subsection{Prevalence of Helminth Infection}

During the present study, different helminth parasites belonging to two classes; cestoda and nematodes were observed. A total of 557 specimens of fowls were examined during the present study, which revealed $45.96 \%$ (256/557) of infection by helminths in the study area (Table1). Different types of helminth parasites were recovered during the study, including two nematodes Ascaridia galli (41.7\%) and Heterakis gallinarum (7.4\%) and three cestodes i.e., Cotugnia diagnopora (17.6\%), Raillietina tetragona $(11 \%)$, Raillietina cesticillus (6.64\%).

\subsection{Seasonal Prevalence}

The study showed that the prevalence of parasites in fowl was throughout the year, but the prevalence varied from season to season. The highest prevalence was observed during monsoon $65.40 \%$ (121/185) and summer $50.53 \%(94 / 186)$ and least in winter $22.04 \%$ (41/186). During summer 186 fowls were examined, out of which 90 (48.4\%), 16 (8.6\%) and 29 (15.6\%), 20 (10.8\%), 12 (6.5\%) were found to be infected with Ascaridia galli, Heterakis gallinarum, Cotugnia diagnopora, Raillietina tetragona Raillietina cesticillus, respectively. Similarly, during monsoon out of 185 specimens examined, 102 (55.1\%), 20 
(10.8\%), $45(24.3 \%), 26(14.1 \%)$ and $18(9.7 \%)$ were infected with Ascaridia galli, Heterakis gallinarum, Cotugnia diagnopora, Raillietina tetragona Raillietina cesticillus, respectively. However, a lowest prevalence of these helminth parasites was observed during the winter. Out of 186 specimens examined 40 (21.5\%); 5 (2.7\%), 24 $(12.9 \%), 15(8.1 \%)$ and $7(3.8 \%)$ were infected with Ascaridia galli, Heterakis gallinarum, Cotugnia diagnopora, Raillietina tetragona Raillietina cesticillus, respectively (Table 2 and Graph 1). Ascaridia galli was more prevalent in both single and multiple type of infection (Table 3). Thus, the order of prevalence in the study area was monsoon >summer > winter. The Mean Intensity (MI) of the parasite was recorded maximum for Raillietina spp. At the same time Relative Abundance (RA) was highest for Ascaridia galli.

\subsection{Age-wise Prevalence}

Domestic fowls of different age groups were examined. Out of 557 specimens, 268 were growing age (12-24 weeks) fowl and of which, 119 (44.4\%) were infected with helminth parasites, similarly in the 289 adult fowl (32 weeks) specimens, $137(47.40 \%)$ were infected with helminth parasites. Results clearly indicate that, there is no significant age resistance shown by the hosts against helminthic infection. Thus, the hosts of any age group may be exposed to helminthic infections with a slight resistance shown by the growing age fowl because they are kept inside the houses (Table-4).

\subsection{Gender-wise Prevalence}

Out of 557 specimens of Gallus gallus domesticus examined during the present study, 270 were females and 287 were males. A prevalence of $50.37 \%(136 / 270)$ was found in females and in males, 41.81\% (120/287) respectively was observed during the study period. The results show that there is no marked but a slight resistance shown by males as compared to females (Table-5).

Table 1. Overall prevalence of gastro intestinal helminths in Gallus gallus domesticus

\begin{tabular}{|c|c|c|}
\hline $\begin{array}{c}\text { Total no of hosts } \\
\text { examined }\end{array}$ & No of infected hosts & $\begin{array}{c}\text { Prevalence of } \\
\text { infection }\end{array}$ \\
\hline 557 & 256 & $45.96 \%$ \\
\hline
\end{tabular}

Table 2. Season wise prevalence of gastrointestinal helminth parasites in Gallus gallus domesticus

\begin{tabular}{|c|c|c|c|c|c|c|c|c|c|}
\hline \multirow{3}{*}{ Season } & \multirow{3}{*}{$\begin{array}{l}\text { Total no. of } \\
\text { Intestines }\end{array}$} & \multirow{3}{*}{$\begin{array}{c}\text { Infected } \\
\text { intestines }\end{array}$} & \multirow{3}{*}{$\begin{array}{c}\text { Non } \\
\text { Infected } \\
\text { intestines }\end{array}$} & \multirow{3}{*}{$\begin{array}{l}\text { Prevalence } \\
\quad(\%)\end{array}$} & \multicolumn{5}{|c|}{$\begin{array}{l}\text { No. infected intestines with particular parasitic spp. (\% } \\
\text { prevalence) }\end{array}$} \\
\hline & & & & & \multicolumn{2}{|c|}{ Nematodes } & \multicolumn{3}{|c|}{ Cestodes } \\
\hline & & & & & A.G & H.G & C.D & R.T & R.C \\
\hline Winter () & 186 & 41 & 145 & 22.04 & $40(21.5)$ & $5(2.7)$ & $24(12.9)$ & $15(8.9)$ & $7(3.8)$ \\
\hline Summer & 186 & 94 & 92 & 50.53 & $90(48.4)$ & $16(8.6)$ & 29 (15.6) & $20(10.8)$ & $12(6.5)$ \\
\hline Monsoon & 185 & 121 & 64 & 65.05 & $102(55.1)$ & $20(10.8)$ & $45(24.3)$ & $26(14.1)$ & $18(9.7)$ \\
\hline Total & 557 & 256 & 301 & 45.96 & $232(41.7)$ & $41(7.3)$ & 98 (17.6) & $61(11)$ & $37(6.64)$ \\
\hline $\begin{array}{l}\chi^{2} \\
P\end{array}$ & & & & $\begin{array}{l}72.57 \\
0.001\end{array}$ & $\begin{array}{l}48.37 \\
0.001\end{array}$ & $\begin{array}{l}9.605 \\
0.008\end{array}$ & $\begin{array}{l}9.117 \\
0.010\end{array}$ & $\begin{array}{l}3.423 \\
0.181\end{array}$ & $\begin{array}{l}5.340 \\
0.069\end{array}$ \\
\hline
\end{tabular}

(A.G-Ascaridia galli, H.G- Heterakis gallinarum, C.D- Cotugnia diagnopora, R.T- Raillietina tetragona R.C- Raillietina cesticillus) 


\section{Seasonal prevalence of helminth parasites}

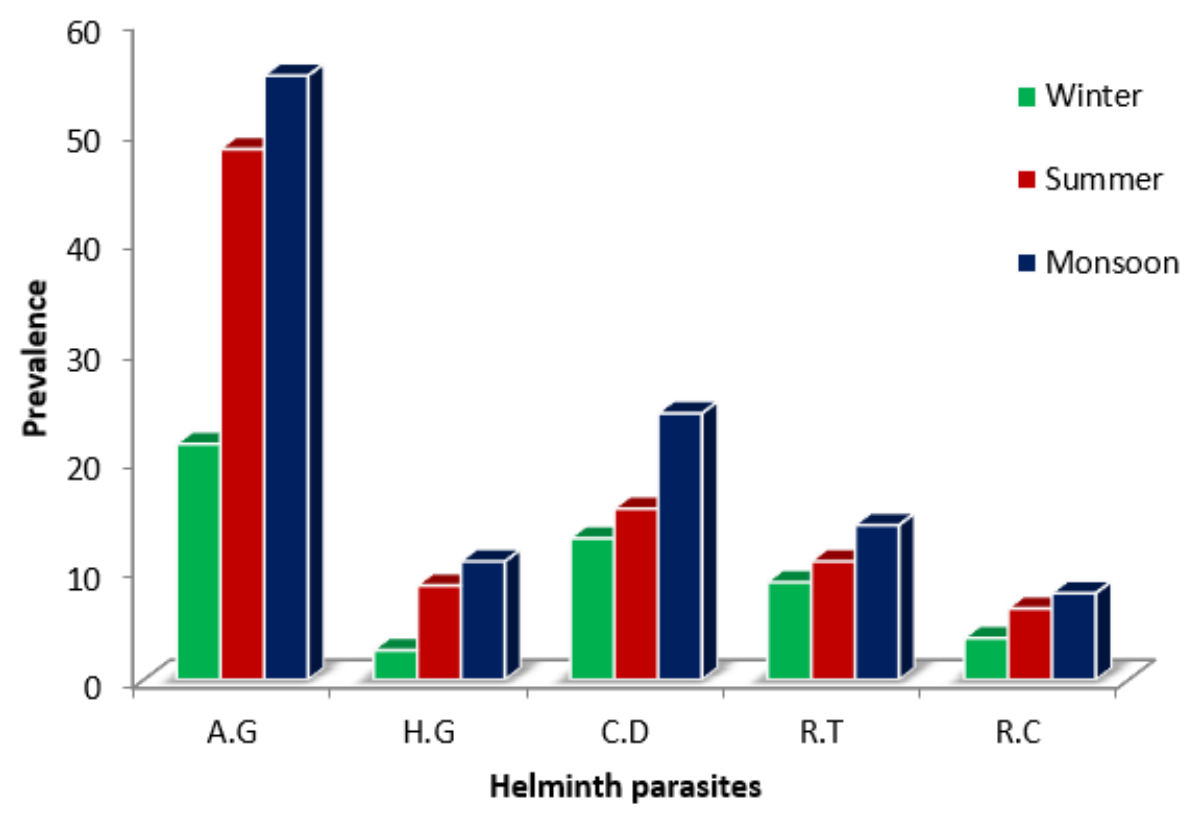

Graph-1. Seasonal prevalence of gastrointestinal helminth parasites in Gallus gallus domesticus

Table 3. Single and multiple species infection of helminth parasites in the gastrointestinal tract of Gallus gallus domesticus

\begin{tabular}{|c|c|c|c|c|}
\hline \multirow{6}{*}{ Single type } & No of hosts examined & Parasitic species & No of infected intestines & Prevalence $(\%)$ \\
\hline & \multirow{7}{*}{557} & Ascaridia galli & 143 & 25.67 \\
\hline & & Heterakis gallinarum & 40 & 7.1 \\
\hline & & Cotugnia diagnopora & 9 & 1.6 \\
\hline & & Raillietina tetragona & 6 & 1.0 \\
\hline & & Raillietina cesticillus & 3 & 0.5 \\
\hline \multirow{2}{*}{ Multiple type } & & $\begin{array}{c}\text { Ascaridia galli }+ \text { Cotugnia diagnopora }+ \\
\text { Raillietina tetragona }\end{array}$ & 55 & 9.8 \\
\hline & & $\begin{array}{c}\text { Ascaridia galli }+ \text { Cotugnia diagnopora }+ \\
\text { Raillietina cesticillus } \\
\end{array}$ & 34 & 6.1 \\
\hline
\end{tabular}

Table 4. Age wise prevalence of gastrointestinal helminths infection in Gallus gallus domesticus

\begin{tabular}{|c|c|c|c|c|}
\hline Age & $\begin{array}{c}\text { Total no. of } \\
\text { Intestine }\end{array}$ & $\begin{array}{c}\text { Non infected } \\
\text { intestines }\end{array}$ & $\begin{array}{c}\text { Infected } \\
\text { intestines }\end{array}$ & Prevalence (\%) \\
\hline Grower & 268 & 149 & 119 & 44.4 \\
\hline Adult & 289 & 152 & 137 & 47.40 \\
\hline Total & 557 & 301 & 256 & $\begin{array}{c}45.96 \\
\chi^{2}=0.505 \\
P=0.478 \\
P>0.05\end{array}$ \\
\hline
\end{tabular}

Table 5. Gender wise prevalence of gastrointestinal helminths infection in Gallus gallus domesticus

\begin{tabular}{|c|c|c|c|c|}
\hline Gender & $\begin{array}{c}\text { Total no of } \\
\text { Intestine }\end{array}$ & $\begin{array}{c}\text { Non infected } \\
\text { intestines }\end{array}$ & $\begin{array}{c}\text { Infected } \\
\text { intestines }\end{array}$ & $\begin{array}{c}\text { Prevalence } \\
(\%)\end{array}$ \\
\hline Female & 270 & 134 & 136 & 50.37 \\
\hline Male & 287 & 167 & 120 & 41.81 \\
\hline Total & 557 & 301 & 256 & $\begin{array}{c}45.96 \\
\chi^{2}=4.10 \\
\mathrm{P}=.043 \\
\mathrm{P}<.05\end{array}$ \\
\hline
\end{tabular}

\section{Discussion}

During the study period overall prevalence of infection was found to be $45.96 \%$, more or less similar to the prevalence (37.6\%) as reported by Agbolade et al. [16]. Among all identified nematode parasites A. galli (57.31\%) was the highest prevalent parasite, similar perevalence of $A$. galli is also reported by Puttalaksshamamma et al. [17]; Katoch et al. [18]: Sreedevi et al. [19]. Although mortality from A. galli is not significant, may lead to death of infected birds due to the obstruction of intestinal lumen Sreedevi et al. [19]. The prevalence of $H$. gallinarum $(7.4 \%)$ was lower as compared to $A$. galli (41.7\%) infection, but $H$. gallinarum play an important role as a carrier of protozoan parasite, Histomonas meleagridis which cause fatal disease in birds. But in Goromonzi District in Zimbabwe [20] and Bhubaneswar [21] regions $H$. gallinarum was the common nematode identified with $64.62 \%$ and $52.94 \%$ of infection, respectively. Whereas in Greneda [22] and Bangalore regions [17] Raillietina tetragona was the common 
parasite than the other cestode parasites. Trematode parasites were not detected during the study period. It might be due to lack of favourable environment for the perpetuation of the vectors of trematodes. Similar finding in desi fowl were also observed earlier [23-25,17,18].

The present study shows that, single type infections of nematode were more prevalent than multiple types of infections with the cestodes. Contrary, multiple type infections with helminths in domestic fowl was observed by various researchers in the references [26-30].

Overall age-wise prevalence of endoparasites during the study period was $44.4 \%$ and $47.40 \%$ in growers and adults, respectively. No significant relationship was found between the prevalence of infection among chicks and adults $(\mathrm{P}>0.05)$. Significant differences were observed by Paul et al. [31] and Momin et al. [32] in Bangladesh and the infection was highly prevalent in adults. High prevalence of endoparasites in adult birds could be due to their gregariousness as compared to chicks, therefore, exposing them to more intermediate hosts than the former. Moreover, chicks were kept inside to protect them from predators. Contrary Dar et al. [33] and Hembram et al. [34] observed more prevalence in chicks and Molla et al. [35] observed more prevalence in growers than the adult birds.

The gender-wise prevalence of endoparasites in study area was $48.14 \%$ and $40.288 \%$ in female and male birds respectively. Females were more susceptible to endoparasites than males with a statistical significance. The results are contrary with other researchers where no statistical difference was reported [34,36,31] in backyard poultry. This could be due to the voracious feeding habits of female birds especially during egg production, then that of males which are largely selective in nature [34,36,31]. Contrary Radfar et al. [37]; Dar et al. [33]; Momin et al. [32] and Sheikh et al. [38] reported more prevalence of parasitic infections in males than female birds.

Overall seasonal prevalence of endoparasites during study period in Monsoon, summer and winter seasons was $65.05 \%, 50.53 \%$ and $22.04 \%$ respectively. Though the prevalence was high during rainy season, significant $(\mathrm{P}<0.05)$ relationship between the season and prevalence of endoparasites was observed in the present study. The environmental conditions of the study region are hot and humid which are favorable for development and survival of preparasitic stages of parasites and for insects, which in turn act as vectors for helminths leading to increased availability of infective stages for backyard poultry [39], especially during the process of searching the feed. Climatic conditions mainly temperature and humidity may alter the population dynamics of the parasites, resulting in variations in the prevalence and intensity of helminthic infections [23]. Significant relationship between the seasons and prevalence of gastrointestinal parasites was observed during rainy season being more favorable for the prevalence of parasites by Dube et al. [39] and Sreedevi et al. [19] in rural area of Zimbabwe and Gannavaram
(Andhra Pradesh) respectively. The present findings are also in agreement with Mungube et.al [25]; Alam et al. [40] and Hembram et al. [34] who reported higher prevalence of infection during rainy season in semi-arid zone of Eastern Kenya, Bangladesh and Odisha, India respectively. Contrary, Hange et al. [41]; Solanki et al. [42] and Rehman et al. [36] reported highest prevalence of helminth infection in winter season compared to summer and rainy seasons. High prevalence of endoparasites during summer season than winter and rainy seasons in free ranging birds was reported by Paul et al. [31]; Naphade et al. [43] and Sheikh et al. [44]. The high prevalence rate of gastrointestinal parasitism in desi fowl in the present study could be attributed to the fact that the desi fowl were free ranging and had free access to infective stages in the environment and to their respective intermediate hosts like beetles, earth worms, ants etc. in search of feed as they act as intermediate hosts for helminth parasites. In the present study, nematodes viz., Ascaridia galli (41.7\%) and Heterakis gallinarum $(7.4 \%)$ and three cestodes i.e., Cotugnia diagnopora (17.6\%), Raillietina tetragona $(11 \%)$, Raillietina sp. (6.64\%) were observed. In case of ascaridiosis the lumen of the intestine was filled with thick white pasty mucus, intestinal blockage due to numerous Ascaridia galli worms of varying sizes, thickening of intestinal wall with velvety appearance of mucosa and enteritis was noticed and the findings were in accordance with the reports of Salam [46] and Bsrat et al. [45] and increased goblet cell activity was clearly evident. However, Bsrat et al. [45] also observed diffuse haemorrhages on mucosal layer, mucoid frothy intestinal fluid, ulceration and mild enteritis with foci at different areas of intestine. In heterakiosis, the caecum revealed thickening of caecal mucosa with small slender worms in the lumen causing nodular typhlitis similar to the reports of Rabbi et al. [24]. Microscopically cross sections of parasites in the lumen along with cellular debris, infiltration of lymphocytes, heterophils and macrophages were also found [46]. The lesions recorded were similar to the observations made by Salam a [46], Salam b [47] in backyard poultry.

Chemical control of helminth parasites is simple, low-priced and can be used both therapeutically and prophylactically against helminths. Helminth parasites treated with chemicals have several drawbacks like weakening of natural immunity and presence of drug residues in food products and in environment $[48,49]$. Chemical anthelmintics (piperazine, albendazole, levamisole, Ivermectin, benzimidazoles and fenbendazole) can stimulate resistance, so there is need of alternative ways to control helminths [50]. There are several medicinal plants which have anthelmintic activity and slow rate of resistance. Medicinal plants which show in vitro anthelmintic activity include Anacardium occidentale, Allium sativum, Tribulus terrestris, Bassia latifolia, Piper betle, Morinda citrifolia L.I, Cassia occidentalis L. and Aloe secundiflora, whereas in vivo studies include the 
usage of Psorelia corylifolia, Piper betle, Pilostigma thonningi, Caesalpinia crista, Ocimum gratissimum and Anacardium occidentale, [50]. In UK nematode parasites were treated with chenopodium oil from many years, obtained from Chenopodiumam brosioides. As well as, male fern Dryopteris filix-mas and Artemisia spp. plants have tendency against cestodes such as Moniezia spp. and nematodes, such as Ascaridia spp. [51]. There are several medicinal plants have good anthelmintic potential in poultry and may be a good alternative of synthetic drugs, and their use will not cause drug resistance in pathogen populations and drug residues in poultry meat.

\section{Conclusions}

Gastrointestinal helminth parasites were studied in domestic fowls. Only 2 genuses of nematodes and 3 genuses of cestodes were identified but trematodes were not detected during present study. Pathologically gross lesion was observed so; further studies should be conducted to know the pathology and such gastrointestinal helminth parasites. This study on prevalence of gastrointestinal parasites in desi fowls suggests ways and means to formulate the appropriate strategies as one of the control measures to get the maximum benefit by rearing of backyard poultry in rural areas. Proper anthelmintic drugs in proper dose and hygienic environment can minimize the risk of helminth infection. Economic losses per year should be estimated to explain the better control program caused by these helminth parasites.

\section{Acknowledgement}

Authors acknowledge to Honourable Vice-Chancellor Prof. Sanjay Singh and other authorities of the University for providing necessary infrastructural facilities to carry out the research work. We are thankful to the people in Lucknow to carries out the study in their area.

\section{REFERENCES}

[1] A. Permin and H. Ranving. Genetic resistance to Ascaridia galli infections in chickens. Vetrinary Parasitol Vol.102, No.1-2, 101-111, 2001.

[2] United States Department of Agriculture (USDA). "International egg and poultry review". U S Department of Agriculture (USDA), 14: 34, 2011.

[3] S.J. Oniye, P.A. Audu, D.A. Adebote, B.B. Kwaghe, O.J. Ajanusi, M.B. Nfor. Survey of Helminth Parasites of Laughing Dove Streptopelia senegalensis, in Zaria, Nigeria. African Journal of Natural Sciences, Vol.4, 65-66, 2001.

[4] D. Frantovo, Some parasitic nematodes, Nematoda of birds,
Aves. In the Czech Republic. Acta Societatis Zoological Bohemicae, Vol.4, 11-13, 2000.

[5] F. T. W. Jordan, M. Pattison. Poultry Diseases. W.B. Saunders Company Ltd, London, 546, 1996.

[6] D.B. Gary, D.M. Richard. Intestinal parasites in backyard chicken flock 1 In: VM 76, Series of Veterinary MedicineLarge animal clinical sciences, University of Florida, 2012.

[7] Lucknow District Population Census. Uttar Pradesh literacy sex ratio and density". Census 2011. Retrieved 4 August 2014.

[8] Lucknow (District, Uttar Pradesh, India). Population statistics, map and location". City population. 10 January 2014. Retrieved 4 August 2014.

[9] Lucknow Minimum Temperature. The Times of India. 29 December 2012

[10] https://www.google.co.in/search?q=full+lucknow+city+ma

[11] N.G. Fowler. How to carry out a field Investigation In: Poultry Diseases, FTW (2nd edn.), Bailliere Tindall, Londanpp, 370-400, 1990.

[12] RM. Cable. An Illustrated Laboratory Manual of Parasitology, (4th edn.) Burgess Publishing Co, 426, South Sixth Street, Minneapolis 15, Minnesota, 1957.

[13] E.J.L. Soulsby Helminthes, Arthropods and Protozoa of domesticated animals. Bailliere Tindall, London, 1982.

[14] L. Margolis, W. Esch, J.C. Holmes, A.M. Kuris, G.A. Schad The use of ecological terms in parasitology (Report of an Ad Hoc Committee of the American Society of Parasitologists). J Parasitol, Vol.68, No.1, 131-133, 1982.

[15] A.O. Bush, K.D. Lafferty, J.M. Lotz, A.W. Shostak. Parasitology meets ecology on its own terms: Margolis et al. revisited. J Parasitol, Vol.83, No.4, 575-583, 1997

[16] O.M. Agbolade, A.S. Arosoye, E.C. Akajiugo, H.A. Akinyemi, A.M. Owolowo, O. Ariba, K. A. Jonathan. Gastrointestinal parasites of domestic fowls from Ijebu north, south-western Nigeria. Basic Research Journal of Agricultural Science, Vol.3, No.7, 60-64, 2014.

[17] G.C. Puttalaksshmamma, K.J. Ananda, P.R. Prathiush, G.S Mamatha, R. Suguna. Prevalence of gastrointestinal parasites of poultry in and around Banglore. Veterinary World, Vol.1, No.7, 201-202, 2008.

[18] Katoch, A. Yadav, R. Godara, J.K. Khajuria, S. Borkataki, S.S. Sodhi. Prevalence and impact of gastrointestinal helminths on body weight gain in backyard chickens in subtropical and humid zone of Jammu, India. J Parasit Dis, Vol. 36, No.1, 49-52, 2012.

[19] C. Sreedevi, Ch. Jyothisree, V. Rama Devi, P. Annapurna, L. Jeyabal. Seasonal prevalence of gastrointestinal parasites in desi fowl (Gallus gallus domesticus) in and around Gannavaram, Andhra Journal of parasitic diseases, Vol.40, No.3, 656-61, 2016

[20] A. Permin, J.B. Esmann, C.H. Hoj, T. Hove, S. Mukaratirwa. Ecto and endo haemoparasites in free-range chickens in the Goromonzi District in Zimbabwe. Preventive Veterinary Medicine, Vol.54, No.3, 213-224, 2002. 
[21] D. Manaswini. Incidence of gastrointestinal helminths of desi fowls in Bhubaneswar area. Intas Polivet, Vol.8, No.1, 200-201, 2007.

[22] R.D. Pinckney, C. Coomansingh, M.I. Bhaiyat, A. Chikweto, R. Sharma. Prevalence of gastrointestinal parasites in free-range poultry in Grenada, West Indies. West Indian Veterinary Journal, Vol.8, No.1, 23-26, 2008.

[23] H.B. Magwisha, A.A. Kassuku, N.C. Kyvsgaard, A. Permin. A comparison of the prevalence and burdens of helminth infections in growers and adult free-range chickens. Tropical Animal Health and Production, Vol.34, No.3, 205-214, 2002.

[24] A.K.M.A. Rabbi, A. Islam, S. Majumder, Anisuzzaman, M.H. Rahman. Gastrointestinal helminths infection in different types of poultry. Bangladesh Journal of Veterinary Medicine, Vol.4, No. 1, 13-18, 2006.

[25] E.O. Mungube, S.M. Bauni, B.A. Tenhagen, L.W. Wamae, S.M. Nzioka, L. Muhammed, J.M. Nginyi. Prevalence of parasites of the local scavenging chickens in a selected semi-arid zone of Eastern Kenya. Tropical animal health production, Vol.40, No.2, 101-109, 2008.

[26] A. Permin, M. Bojesen, P. Nansen, M. Bisgaard, F. Frandsen, M. Pearman. Ascaridia galli populations in chickens following single infections with different dose levels. Parasitol Res, Vol. 83, No.6, 614-617, 1997.

[27] AK. Yadav, V. Tandon. Helminth Parasitism of Domestic fowl (Gallus domesticus L) in a subtropical high rainfall area of India. Br Vet J, Vol.145, 57-61, 1989.

[28] M. Mpoame, G. Agbede. The Gastrointestinal helminth infection of domestic fowl in Dschang, Western Cameroon. Rev Elev Med Vet Pays Trop, Vol.48, 147-151, 1995.

[29] I.K. Phiri, A.M. Phiri, M. Ziela, A. Chota, M. Masuku, M. Jesper. Prevalence and distribution of gastrointestinal helminthes and their effects on weight gain in free range chickens in Central Zambia. Tropical Animal Health and Production, Vol. 39, No.4, 309-315, 2007.

[30] H.B. Magwisha, A.A. Kassuka, N.C. Kyvsgaard, A. Permin. A comparison of the prevalence and burden of helminth infections in growers and adults free range chickens. Tropical Animal health and Production, Vol.34, No.3, 205-214, 2002.

[31] D.R. Paul, A.R. Dey, F. Bilkis, N. Begum, M.M.H. Mondal. Epidemiology and pathology of intestinal helminthiasis in fowls. Eurasian Journal of Veterinary Sciences, Vol. 28 No.1, 31-37, 2012.

[32] M.A. Momin, N. Begum, A.R. Dey, S.M. Paran, M.Z. Alam. Prevalence of blood protozoa in poultry in Tangail, Bangladesh. IOSR Journal of Agriculture and Veterinary Science, Vol. 7, No.7, 55-60, 2014.

[33] J.A. Dar, S. Tanveer. Prevalence of cestode parasites in free-range backyard chickens (Gallus gallus domestics) of Kashmir, India. Agriculture and biology Journal of North America, Vol. 4, No.1, 67-70, 2013.

[34] A. Hembram, M.R. Panda, B.N. Mohanty, C.R. Pradhan, M. Dehuri, A. Sahu, M. Behera. Prevalence of gastrointestinal helminths in Banaraja fowls reared in semi intensive system of management in Mayurbhanj district of Odisha.
VeterinaryWorld, Vol.8, No.6, 723-726, 2015.

[35] W. Molla, H. Haile, G. Almaw, W. Temesgen. Gastrointestinal helminths of local backyard chickens in North Gondar Administrative Zone, Ethiopia. Revue Méd.Vét, Vol. 163, No.7, 362-367, 2012.

[36] T. Rehman, L. Zada, A. Ahmad, M.A. Zeb. Prevalence rate of Raillietina cesticillus in domestic chickens of District Mardan, KPK, Pakistan. International Journal of Medicine \& Biomedical Sciences Vol.1, No.2, 13-16, 2016.

[37] M.H. Radfar, J. Khedri, K. Adinehbeigi, R. Nabavi, K. Rahmani. Prevalence of parasites and associated risk factors in domestic pigeons (Columba livia domestica) and free-range backyard chickens of Sistan region, east of Iran. Journal of Parasitic Diseases, Vol.36, No.2, 220-225, 2012.

[38] B.A. Sheikh, T.A. Sofi, F. Ahmad. Prevalence of helminth parasites in Gallus domesticus from Gurez valley. Agricultural Advances Vol.4, No.11, 129-137, 2015.

[39] S. Dube, P. Zindi, J. Mbanga, C. Dube. A study of scavenging poultry gastrointestinal and ecto-parasites in rural areas of Matebelel and Province, Zimbabwe. International Journal of Poultry Science, Vol.9, No.9, 911-915, 2010.

[40] M.N. Alam, M. Mostofa, M.A.H.N.A, Khan, M.A. Alim, A.K.A. Rahman. Prevalence of gastrointestinal helminth infections in indigenous chickens of selected areas of Barisal district, Bangladesh. Bangladesh Journal of Veterinary Medicine, Vol.12, No.2, 135-139, 2014.

[41] R.R. Hange, Y.V. Raote, A.K. Jayraw. Prevalence of helminth parasites in desi fowl (Gallus gallus domesticus) at Parbhani. Journal of Parasitic Diseases, Vol.31, No.1, 61-64, 2007.

[42] J.B. Solanki, N. Kumar, A. Varghese, B.J. Thakre, G. Puri Prevalence of gastrointestinal parasitism in poultry in and around Navsari area of South Gujarat. Livestock Research International, Vol.3, No.1, 28-30, 2015.

[43] S.T. Naphade, K.V. Chaudhari. Studies on the seasonal prevalence of parasitic helminths in Gavran (desi) chickens from Marathwada region of Maharashtra. International Journal of Fauna and Biological Studies, Vol.1, No.2, 4-7, 2013.

[44] B.A. Sheikh, T.A. Sofi, F. Ahmad. Prevalence of helminth parasites in Gallus domesticus from Gurez valley. Agricultural Advances, Vol. 4, No.11, 129-137, 2015.

[45] A. Bsrat, T. Tesfay, Y. Tekle. Clinical, gross and histopathological study on common local chicken diseases in Enderta district, south east Tigray. European Journal of Biological Sciences, Vol.6, No.4, 95-103, 2014.

[46] S.T. Salam. Ascariasis in backyard chicken - prevalence, pathology and control, International Journal of Recent Scientific Research, Vol.6, No.4, 3361-3365, 2015a.

[47] S.T. Salam. Ascariasis in backyard chicken - prevalence, pathology and control, International Journal of Recent Scientific Research, Vol.6, No.4, 3361-3365, 2015 b.

[48] S.M. Thamsborg, A. Roepstorff, M. Larsen. Integrated and biological control of parasites in organic and conventional production systems. Veterinary Parasitol, Vol. 84,169-186, 1999. 
[49] J. Vercruysse, P. Dorny. Integrated control of nematode infections in cattle: a reality, a need, a future. Int J Parasitol, Vol. 29, 165-175, 1999.

[50] A. Raza, F. Muhammad, S. Bashir, B. Aslam. In-vitro and in-vivo anthelmintic potential of different medicinal plants against Ascaridia galli infection in poultry birds. World poultry science journal, Vol. 72, No. 1, 115-124, 2016.

[51] British Veterinary Codex (1965) British Veterinary Codex. The Pharmaceutical Press, London. 